\title{
Game Pembuatan Beras Mocaf Berbahan Dasar Tepung Mocaf "Beras Mocaf, Let's Do It"
}

\author{
Zata Dini Astuti ${ }^{*}$, Eko Budi Cahyono ${ }^{2}$, Wildan Suharso ${ }^{3}$ \\ 1,2,3Teknik Informatika/Universitas Muhammadiyah Malang \\ zdini44@gmail.com*
}

\begin{abstract}
Abstrak
Indonesia merupakan daerah tropis yang kaya akan hasil sumber daya alam. Salah satu hasilnya adalah umbi-umbian seperti singkong. Masih banyak masyarakat yang tidak mengetahui bahwa singkong dapat diolah menjadi beras yang dikenal dengan beras analog yang merupakan beras tiruan berbahan dasar selain beras dan terigu. Telah dilakukan penelitian terhadap klaster industry kecil pengolahan ubi kayu dan klaster industry pengolahan tepung mocaf, yang bertujuan untuk membantu mengembangkan model jaringan bisnis social dan pengembangan prototip teknologi jaringan bisnis sosial pelaku usaha berbahan baku ubi kayu di desa Tirtoyudo Kecamatan Tirtoyudo kabupaten Malang. Telah dibentuk 6 tim untuk membantu penelitian tersebut yang memiliki tugas masing-masing salah satunya Game pembuatan beras mocaf berbahan dasar tepung mocaf, game ini menggunakan metode GDLC (Game Development Life Cycle). Hasil dari game bergendre simulasi ini dapat membantu pola pikir masyarakat dalam memahami dan mengetahui setiap proses cara pengolahan beras mocaf berbahan dasar tepung mocaf.
\end{abstract}

Kata Kunci: Game, Edukasi, Mocaf, Simulasi

\begin{abstract}
Indonesia is a tropical region rich in natural resource yields. One result is tubers like cassava. There are still many people who do not know that cassava can be processed into rice known as analog rice which is artificial rice based on rice and wheat. Research on small industry clusters of cassava processing and cluster of mocaf flour processing industry, which aims to help develop social network business model and prototype development of business social network technology of cassava business in Tirtoyudo village, Tirtoyudo district, Malang regency. 6 teams have been set up to help the research that has the task of each one of them Game making mocaf rice made from mocaf flour, this game using the method of GDLC (Game Development Life Cycle). The results of this simulated game can help the mindset of the community in understanding and knowing every process of processing mocaf mocaf made from mocaf flour.
\end{abstract}

Keywords: Game, Education, Mocaf, Simulation

\section{Pendahuluan}

Indonesia merupakan daerah tropis yang kaya akan hasil sumber daya alam. Salah satu hasilnya adalah umbi-umbian seperti singkong [1]. Di Indonesia singkong dijadikan makanan pokok nomor 3 setelah padi dan jagung pada tahun 1914-1981. Indonesia kekurangan bahan pangan (makanan) beras, sehingga sebagai alternative pengganti makanan pokok diperkenalkanlah singkong pada tahun 1968 Indonesia menjadi negara pengahasil ubi kayu nomor 5 di dunia [2]. Bahan pokok utama masih bertumpu pada beras, meskipun di beberapa daerah kecil penduduk mengonsumsi pangan pokok non beras seperti jagung atau komuditi lainnya (singkong)[3]. Terdapat banyak kandungan pada singkong seperti karbohidrat, selain itu terdapat kandungan gizi seperti protein, vitamin c, kalsium, posfor, kalori, lemak, zat besi, dam vitamin $B_{1}$. Dengan berbagai kandungan gizi yang terdapat pada singkong maka sangat baik untuk dikonsumsi masyarakat [1].

Masih banyak masyarakat yang tidak mengetahui bahwa singkong dapat diolah menjadi beras yang dikenal sebagai beras analog yang dapat menjadi alternative pengganti beras padi. Beras analog merupakan beras tiruan yang terbuat dari bahan baku selain beras dan terigu [4]. Dalam hal ini dapat saja membantu perekonomian petani singkong untuk meningkatkan kesejahteraan hidup mereka. 
Telah dilakukan pernelitian terhadap klister incustri kecil pengolahan ubi kayu dan klister industry pengolahan tepung mocaf, yang bertujuan untuk membantu mengembangkan model jaringan bisnis social dan pengembangan prototip teknologi jaringan bisnis sosisal pelaku usaha berbahan baku ubi kayu di desa Tirtoyudo Kecamatan Tirtoyudo Kabupaten Malang. Masih banyak pelaku usaha ubi kayu memerlukan bantuan (tidak sekedar modal) tetapi dalam bentuk intervans social untuk membangun kohesivitas komunitas yang solid ditengah-tengah dinamika arus informasi dan teknologi yang berkembang [5].

Untuk membantu penelitian tersebut telah dibentuk 6 tim dengan tugas masing-masing salah satunya adalah Game pembuatan beras mocaf berbahan dasar tepung mocaf "Beras mocaf Let's do it'. Game bergendre simulasi ini menggunakan metode GDLC (Game Development Life Cycle), dengan tipe simulasi dapat menggambarkan tentang kehidupan pribadi sehari-hari, kehidupan pekerjaan serta pengaturan dan pengoperasian alat-alat[6]. Game mengadopsi beberapa game yang telah ada yaitu game "Cooking Academy", "Cooking Mama", dan "Chips Potato Factory". Penulis memilih game dikarenakan game dapat digunakan untuk mengasah daya pikir dan logika yang dapat mengenalkan materi agar lebih menarik untuk diterima dan dipahami.

Berdasarkan uraian diatas dapat disimpulkan rumusan masalah yang akan dihadapi yaitu bagaimana merancang game edukasi simulasi dan bagaimana mengimplementasikan sebuah game edukasi simulasi yang menjadi alat bantu untuk mengenal beras mocaf.

\section{Metodelogi}

\subsection{Game}

Akan dijabarkan tentang teori mengenai penulisan dan rancangan game.

Kata game berasal dari Bahasa inggris yang berarti permainan. Menurut Yudhanto game adalah permainan yang menggunakan media elektronik, merupakan sebuah hiburan berbentuk multimedia yang dubuat semenarik mungkin agar pemain bisa mendapatkan sesuatu sehingga adanya kepuasan batin [7].

\subsection{Game Edukasi}

Game mempunyai fungsi dan manfaat positif bagi anak, diantaranya anak mengenal teknologi computer, pelajaran untuk mengikuti arahan dan aturan, latihan memecahkan masalah dan logika. Edukasi sebenarnya tidak jauh berbeda dari belajar yang dikembangkan oleh aliran behabiorisme dalam psikolog. Hanya istilah ini sering dimaknai dan diinterpretasikan berbeda dari learning yang bermakna belajar, dan istilah ini seringkali digunakan dalam pendekatan Pendidikan yang tentu maknanya lebih dari sekedar belajar [8].

\subsection{Game Simulasi}

Game simulasi atau simulation game adalah genre game yang mencoba untuk merepresentasi sistem, mesin, dan pengalaman dengan menggunakan peraturan sebenarnya yang ada di dunia. Mayoritas game simulasi siciptakan untuk tujuan hiburan, namun ada juga institusi pemerintah dan militer yang mengembangkan game simulasi untuk keperluan training dan recruitmen. Tujuan game simulasi adalah agar pemainnya mendapatkan ilmu yang berasal dari game tentang objek atau kegiatan asli dunia [9].

\subsection{Game Development Life Cycle (GDLC)}

Game development life cycle adalah sebuah metode pembangunan dan pengembangan game, dimana didalamnya ada tahapan inititatio, pre-production, production, testing, beta, release, Gambar 1 berikut ini penjelasan singkat tentang tahapan-tahapan game development life cycle yang biasa disingkat GDLC[10]

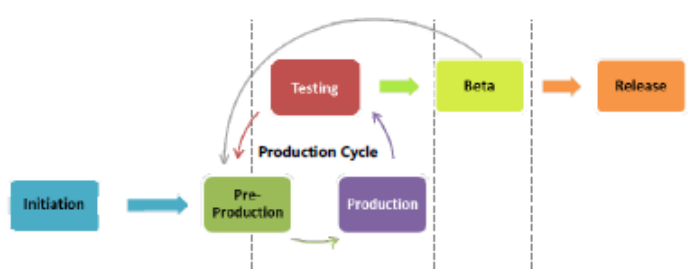

Gambar 1. Metode Game development Life Cycle

REPOSITOR, Vol. 2, No. 4, April 2020: 437-446 
a. Initiation

Initiation adalah sesi developer berkumpul, brainstorming dan berdiskusi mengenai game seperti apa yang akan dibuat. Proses pengembangan game yang betul-betul serius dimulai dari proses iterative yang bernama production cycle.

b. Pre-production

Pre-production adalah tahap yang vital sebelum proses production dimulai, karena pada tahap ini dilakukan perancangan game, dan rencana produksi game. Tahap ini berdiri atas game design yakni penyempurnaan konsop game + dokumentasinya (Game design document) dan prototyping yakni pembuatan prototype dari gamei.

c. Production

Game design dan prototype yang ada pada pre-production disempurnakan pada production. Artinya, tahap ini memiliki focus pada menerjemahkan rancangan game design, concept art, dan aspek-aspek lainnya menjadi unsur penyusun game.

d. Testing

Testing merupakan pengujian terhadap prototype build. Pengujian ini dilakukan oleh internal developer team untuk melakukan usability test dan fungtionality test.

e. Beta

Beta test dikenal dengan eksternal testing yang dilakukan untuk menguji keberterimaan game dan untuk mendeteksi berbagai error dan keluhan yang dilemparkan oleh third party tester. Beta berada diluar production cycle, tetapi hasil testing ini berpotensi menyebabkan tim mengulangi production cycle.

f. Release

Game yang sudah selesai dibuat dan lulus beta testing menandakan game tersebut siap untuk dirilis ke public.

\subsubsection{Gameplay}

Cara bermain pda permainan yang akan dubuat ini yaitu pemain berinteraksi dengan permainan, pemain akan diperintahkan menekan beberapa tombol dilayar smartphone android untuk memainkan permainan ini. terdapat beberapa tantangan berupa waktu disetiap langkahnya, apabila pemain berhasil menyelesaikan permainan sesuai dengan instruksi maka pemain akan mendapatkan skor akhir. Gambar 2 berikut ini gameplay dari permainan.

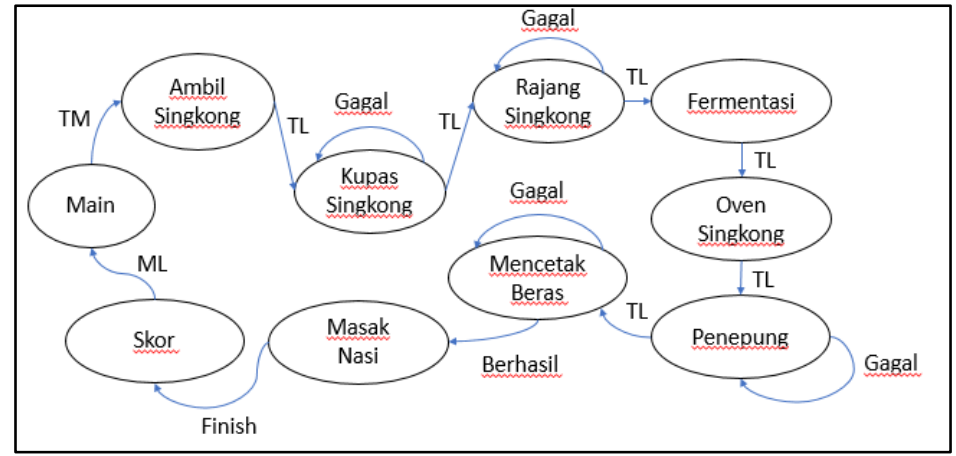

Gambar 2. FSM Gameplay

Keterangan:

TM : Tekan tombol main

TL : : Tekan Lanjut

ML : Main Lagi

Gagal : Pemain tidak berhasil melakukan tahap permainan

Berhasil: Pemain berhasil membuat beras

Finish : Pemain menyelesaikan permainan

Pada Gambar 2 main adalah pada saat aplikasi berjalan lalu pemain masuk ke langkah pembuatan beras mocaf mulai dari ambil singkong, kemudian lanjut ke kupas singkong dan apabila gagal pemain harus mengulang kupas singkong kembali, lanjut kebagian rajang singkong sama seperti langkah sebelumnya apabila pemain gagal diharuskan mengulang rajang singkong, kemudian lanjut ke langkah fermentasi, oven singkong, penepung, lalu cetak beras. Setelah 
berhasil mencetak beras, lanjut ke memasak nasi, terdapat tantangan berupa waktu yang mana pemain tidak boleh kehabisan waktu sebelum indicator permainan terpenuhi, setelah permainan telah selesai dilalui maka pemain mendapatkan skor dan pemain dapat mengulang permainan dari awal.

\subsubsection{Desain}

Berikut ini merupakan rancangan game

\subsubsection{Karakter}

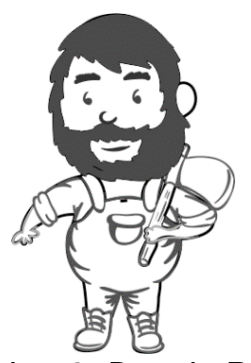

Gambar 3. Desain Petani

Karakter utama pada Gambar 3 adalah karakter petani yang membawa cangkul dibahunya, yang bertugas untuk mengarahkan para pemain langkah-langkah untuk membuat beras mocaf.

\subsubsection{Rancangan Alur Sistem}

Rancangan alur sistem dalam permainan ini akan menggunakan media gambar. Tujuan dari rancangan alur sistem ini adalah agar pemain dapat memahami alur dari sistem yang telah dirancang dengan melihat gambar-gambar yang sudah tersusun.

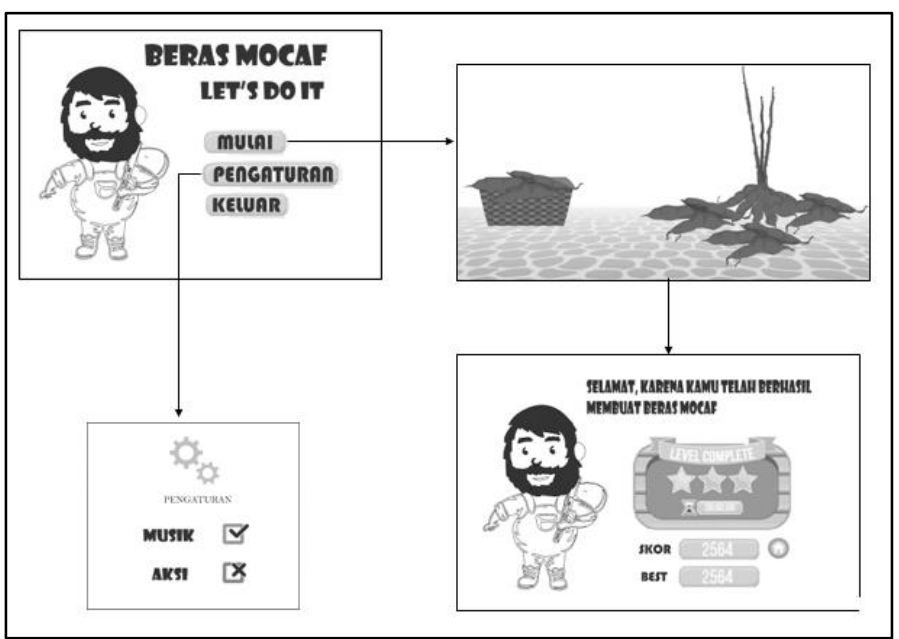

Gambar 4. Rancangan Alur Sistem

Pada Gambar 4, di menu utama terdapat beberapa pilihan. Terdapat menu "pengaturan" dimana pemain dapat mengatur musik dan suara aksi pada permainan. Pemaian dapat memulai permainan dengan memilih menu "Mulai". Pada awal permainan, pemain akan terlebih dahulu menjumpai petani yang akan menjelaskan setiap langkah bagaimana menyelesaikan permainan. Pada akhir permainan pemain akan melihat skor yang didapat dari permainan yang telah dilaluinya dan dapat memulai kembali permainan. Ada menu "Keluar" untuk keluar dari aplikasi.

\section{Hasil dan Pembahasan}

Pada tahap ini akan menjelaskan hasil pembuatan game yang sudah didesain pada tahap sebelumnya.

REPOSITOR, Vol. 2, No. 4, April 2020: 437-446 
3.1 Implementasi Karakter

Berikut ini merupakan tampilan dari karakter dan mesin-mesin pada permainan.

a. Karakter

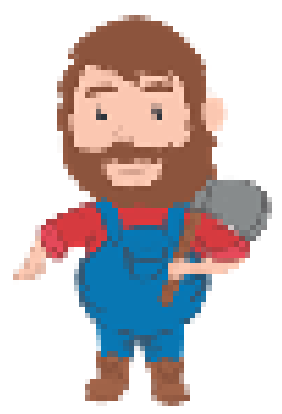

Gambar 5. Implementasi Petani

Gambar 5 diatas merupakan implementasi tampilan dari petani yang telah didesain sebelumnya.

\section{b. Mesin Pada Game}

Gambar 6 berikut ini merupakan mesin yang ada pada game, mulai dari mesin pengupas singkong, perajang singkong, penepung, pencetak.

- Mesin Pengupas

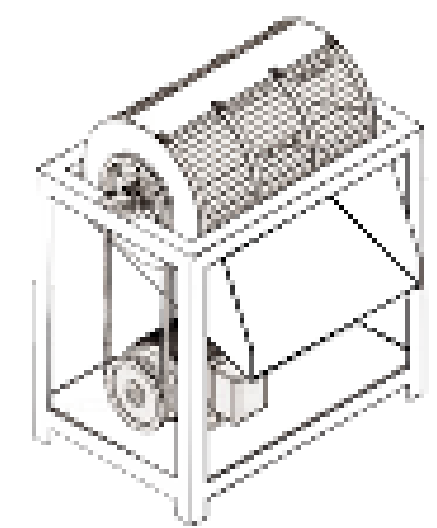

Gambar 6. Mesin Pengupas Singkong

Ini merupakan implementasi tampilan dari mesin pengupas singkong yang digunakan untuk mengupas kulit singkong.

- Mesin Perajang

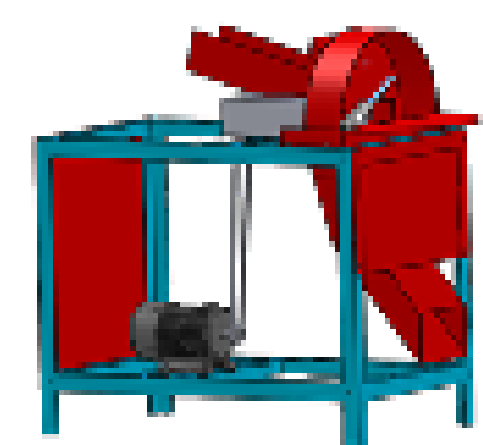

Gambar 7. Mesin Perajang Singkong 
Pada Gambar 7 ini merupakan implemenyasi tampilan dari mesin perajang singkong yang digunakan untuk memotong singkong menjadi bagian kecil yang disebut chips.

- Mesin Penepung

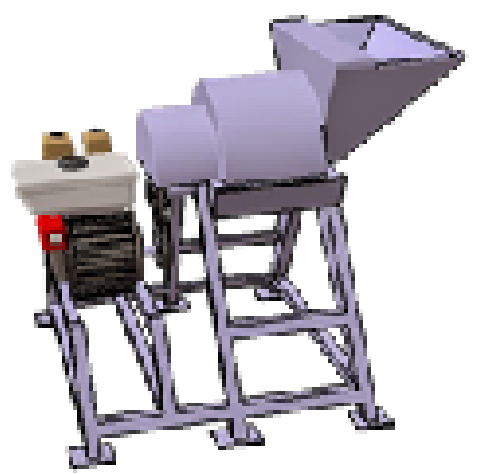

Gambar 8. Mesin Penepung Singkong

Gambar 8 merupakan tampilan implementasi dari mesin penepung yang berfungsi untuk mengolah chips menjadi tepung mocaf.

- Mesin Pencetak

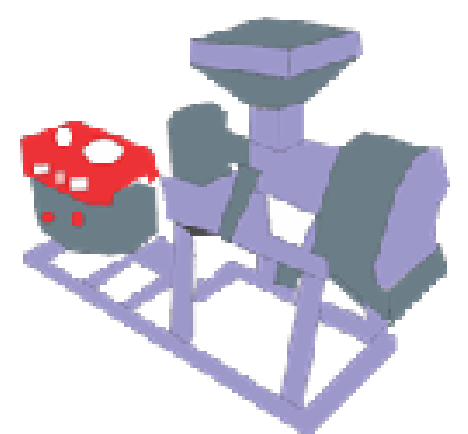

Gambar 9. Mesin Pencetak Beras

Gambar 9 merupakan implementasi dari mesin pencetak beras yang digunakan untuk mencetak tepung mocaf yang telah menjadi adonan dengan mencampurkan tepung dengan air menjadi beras.

\subsection{Implementasi Modul Antarmuka}

Pada tampilan antarmuka akan menjabarkan tentang implementasi modul tampilan awal hingga bermain.

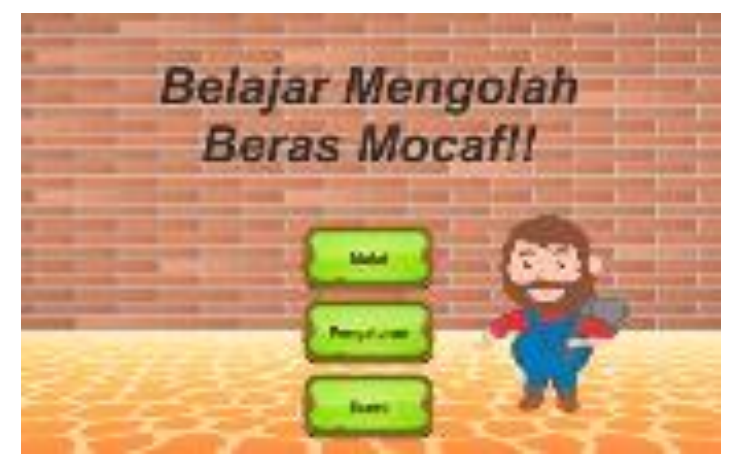

Gambar 10. Tampilan Awal

REPOSITOR, Vol. 2, No. 4, April 2020: 437-446 
Pada tampilan awal pada Gambar 10, pemain dapat memilih menu main, menu pengaturan dan menu keluar.

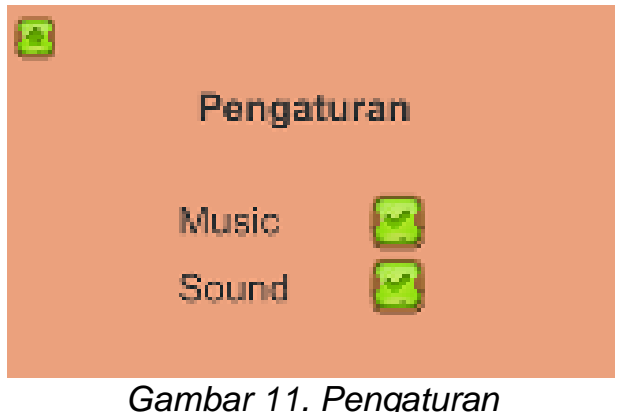

Ketika pemain memilih menu pengaturan, pemain akan masuk ke tampilan pengaturan, pemain dapat menyalakan dan mematikan suara dam game pada pengaturan yang telihat pada Gambar 11.

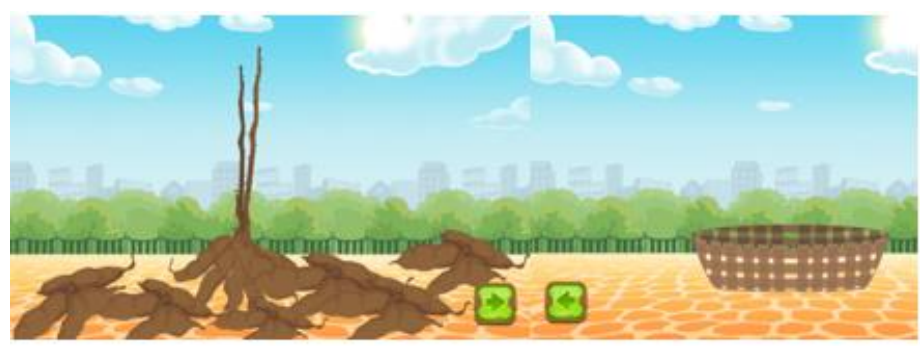

Gambar 12. Gameplay Ambil Singkong

Ketika pemain memilih menu main, pemain akan masuk kepermainan ambil singkkong. Pada Gambar 12 pemain diminta untuk memasukkan singkong ke dalam keranjang yang telah disediakan. Jika pemain telah selesai maka pemain akan melanjutkan permainan yaitu mengupas singkong.

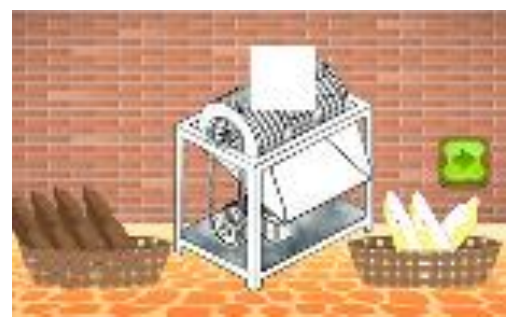

\section{Gambar 13. Gameplay Mengupas Kulit Singkong}

Singkong yang telah diambil lanjut dimasukkan kedalam mesin pada Gambar 13. Mesin akan beroperasi dan mengeluarkan singkong yang telah terpisah dengan kulitnya kedalam keranjang. Mesin akan secara otomatis mengaktifkan anisami ketika singkong telah dimasukkan kedalam mesin, dan mesin akan mengeluarkan singkong tanpa kulit.

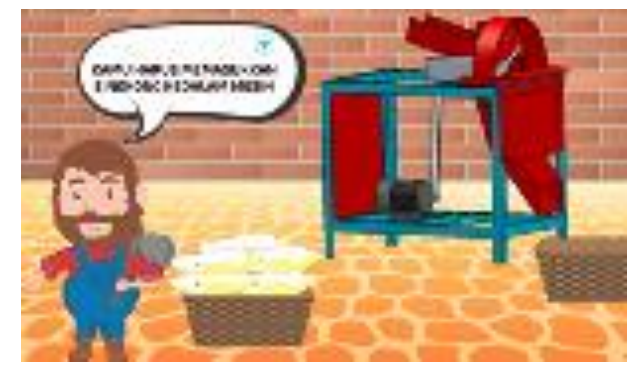

Gambar 14. Tampilan Petani

Game Pembuatan Beras Mocaf Berbahan... Zata Dini Astuti, Eko Budi Cahyono, Wildan Suharso 
Pada Gambar 14 merupakan tampilan petani yang akan mengarahkan apa yang harus dilakukan pemain pada setiap langkahnya.

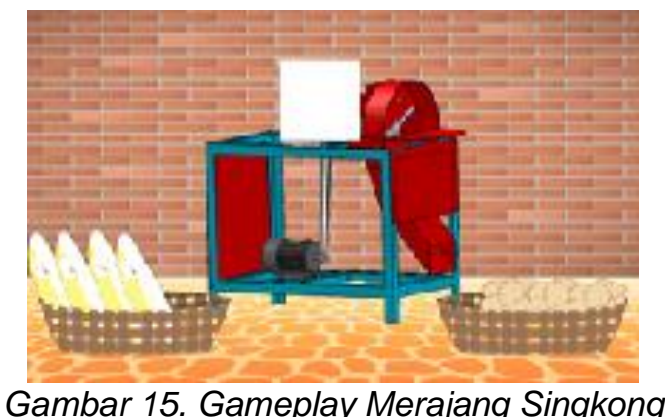

Pemain yang berhasil menyelesaikan permainan akan masuk ke langkah selanjutnya yaitu proses perajangan singkong terlihat pada Gambar 15, sama dengan permainan sebelumnya pemain diminta untuk memasukkan singkong ke dalam mesin sehingga menghasilkan chips.

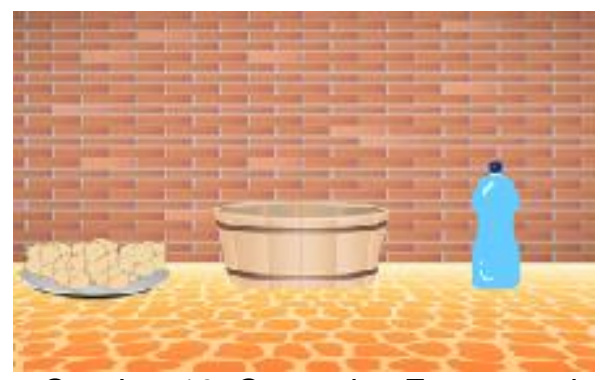

Gambar 16. Gameplay Fermentasi

Pada langkah selanjutnya pada Gambar 16 pemain diminta untuk memasukkan chips dan air ke dalam bak. Terdapat waktu fermentasi, ketika waktu habis pemain harus membuang air dari dalam bak.

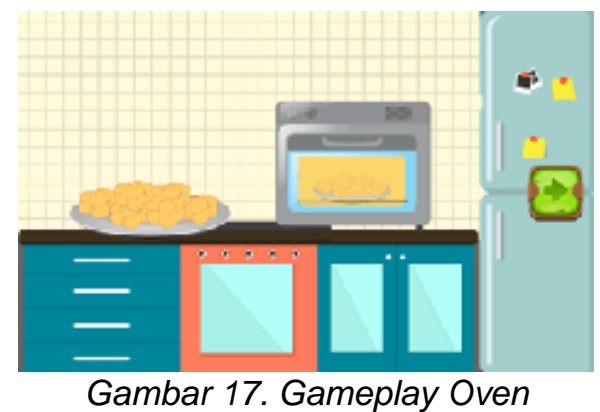

Pada proses ini Gambar 17 pemain memasukkan chips ke dalam oven untuk proses pengurangan kadar air pada chips, sehingga memudahkan pada proses selanjutnya.

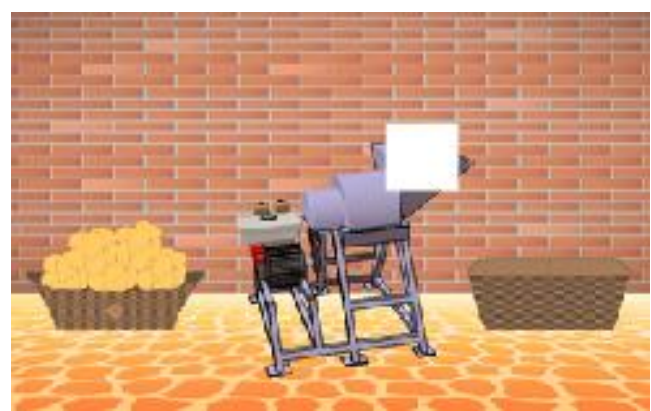

Gambar 18. Gameplay Penepungan

REPOSITOR, Vol. 2, No. 4, April 2020: 437-446 
Selanjutnya Gambar 18 masuk pada proses penepungan, pada proses ini sama seperti permainan sebelumnya bahwa pemain harus memasukkan chips yang telah dioven ke dalam mesin penepung untuk menjadikan tepung mocaf.

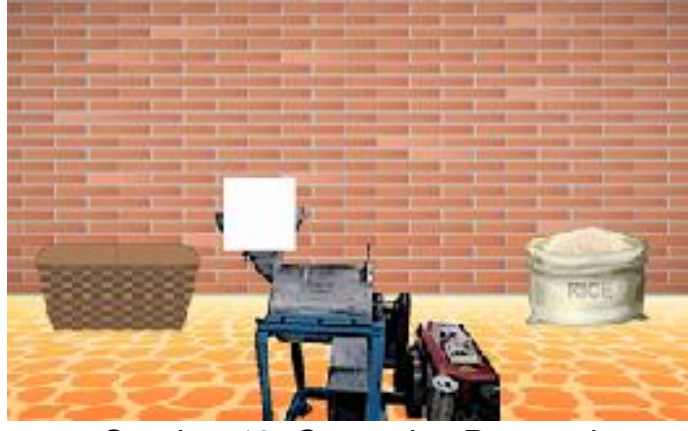

Gambar 19. Gameplay Pencetak

Pada proses selanjutnya pada Gambar 19 , sama seperti sebelumnya pemain diminta untuk memasukkan tepung kedalam mesin pencetak untuk menghasilkan beras mocaf.

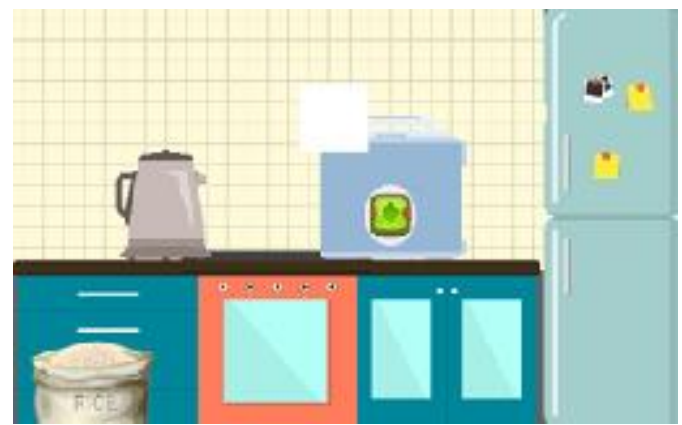

Gambar 20. Gameplay Masak

Pada Gambar 20 merupakan proses terakhir dalam permainan, pemain diminta unruk memasukkan air dan beras ke dalam ricecooker untuk memasak beras menjadi nasi.

\section{Kesimpulan}

Setelah melalui pengerjaan implementasi dan pengujian terhadap sistem, dapat ditarik kesimpulan bahwa fungsionalitas pada aplikasi ini telah berfungsi sebagaimana yang diharapkan, dan pada alur permainan sudah berjalan dengan baik. Selain itu juga ada saran untuk penelitian lebih lanjut sehingga dapat dikembangkan dengan menghubungkan game ke internet, penambahan tingkat kesulitan dalam permainan yaitu apabila pemain gagal harus mengulang permainan, dan perlunya penambahan informasi, yaitu pemberian gambar informasi tentang bagaimana mendapat hight score.

\section{Referensi}

[1] Elvina Novyanti Pulungan, Albiner Siagian, and Ernawati Nasution, "Uji Daya dan Nilai Gizi Brownies Singkong".

[2] Muhammad Thamrin, Ainul Mardhiyah, and Samsul Marpaung, "Analisis Usaha Tani Ubi Kayu" vol. 18, no. 1, pp. 57-64, 2013.

[3] S. Sunarsi, M. S. A, S. Wahyuni, and W. Ratnaningsih, "Memanfaatkan Singkong Menjadi Tepung Mocaf untuk Pemberdayaan Masyarakat Sumberejo," no. 1, 2011.

[4] S. S. Yuwono and A. Ad, "Formulasi Beras Analog Berbasis Tepung Mocaf Dan Maizena Dengan Penambahan CMC Dan Tepung Ampas Tahu Formulation of Analogue Rice Based Mocaf and Maizena Flour with Addition CMC and Tofu Waste Flour," vol. 3, no. 4, pp. 14651472, 2015.

[5] P. Studi, T. Informatika, F. Teknik, and U. M. Malang, "Pelaku Usaha Berbahan Baku Ubi Kayu," pp. 387-393, 2016.

[6] E. S. Kw et al., "Pembuatan Game Simulasi Perkebunan , Peternakan dan Interaksi Sosial," pp. $1-4$. 
[7] A. D. Wulandari, "Game Edukatif Sejarah Komputer Menggunakan Role Playing Game (RPG) Marker XP Sebagai Media Pembelajaran di SMP Negeri 2 Kalibawang," Game Edukatif Sej. Komput. Menggunakan Role Play. Game Marker XP Sebagai Media Pembelajaran di SMP Negeri 2 Kalibawang, 2012.

[8] G. Edukasi, B. Android, S. Media, and P. Untuk, "Game Edukasi Berbasis Android Sebagai Media Pembelajaran Untuk Anak Usia Dini," vol. 1, no. 1, pp. 46-58, 2016.

[9] A. E. Siswojo, P. Desain, K. Visual, F. I. Kreatif, U. Telkom, and G. Simulasi, "Perancangan Game Simulasi “ Sapi Kerap Sebagai Upaya Revitalisasi Budaya Kerapan Sapi ' Sapi Kerap 'Simulation Game Design As An Effort To Revititalize The Kerapan Sapi Culture."

[10] A. V. Games, "Game development life cycle guidelines," no. September 2013, 2016. 